\title{
London University Degrees: a Faraday Letter
}

$\mathrm{A}^{\mathrm{T}}$

$\mathrm{T}$ the recent celebrations of the centenary of the University of London, the Royal Institution presented to the University a letter written by Faraday on August 10, 1859, to the Rev. John Barlow, F.R.S. The special appropriateness of the gift for the occasion lay in the reference the letter contains to that pioneering activity of the University, the institution of degrees in science. With the movement to accord full recognition to science as an object of academic study Faraday was, it is scarcely necessary to say, in complete sympathy. He was indeed actively concerned in the measures taken, for he was a member of the Senate of the University at the time, a circum. stance which adds point to his comments. As this and other points in the letter may be of interest to readers of NATURE, it is printed below.

\section{Hampton Court Green} 10 Aug. 1859

\section{My dear Barlow}

It was very kind of Mrs. Barlow to write to my wife, and I think that a letter from me to you, is hardly the fit way to acknowledge it:-yet as I write to you you must say something fit for us, with our kindest remembrances, and I expect my wife will write soon. We are exceedingly glad to hear that your journey has been good-your company a happy one- \& your present life healthy \& joyous. Before I forget remember me to Mr. Esmead-I cannot tell whether I have been at Spa, or have any friends there; if there are such I dare say you will find them out. We are jogging on or rather we are not jogging on :- for on Monday last the workmen ceased to come, the builders strike being on. As far as I can learn, both Masters \& Men enter quietly into it ; so that though it seems as if it might come to an end in a few days, it may perhaps go on for some time \& cause great distress and trouble. We must just wait.

I am not able to give Mrs. Barlow's message to Tyndall, for I think he started last Monday Morning for Chamounie, and I have not seen him since Saturday. Frankland goes with him. He spoke of taking the higher optics for his next course of lectures, and I agreed with him in the propriety (if he saw occasion) of spending $£ 20$ on apparatus fitted for the course and for investigation. I do not suppose that he will come across any clear good optical rock salt, but we find great difficulty in raising it from the mines in England. Indeed it is rather an impossibility than a difficulty.

As I have been out here with only runs into town I really know very little of what is going on there :and what I learn I forget. The Senate of the University accepted and approved of the Report of the Committee for Scientific degrees, so that that will go forward (if the Government approve) and will come into work next year. It seems to give much satisfaction to all who have seen it, though the subject is beset with difficulties:- for when the depth \& breadth of Science came to be considered, and an estimate was made of how much a man ought to know to obtain a right to a degree in it, the amount in words seemed to be so enormous as to make one hesitate in demanding it from the student :and though in the D.S. one could divide the matter and claim eminence in one branch of Science, rather than good general knowledge in all-still in the B.S. which is a progressive degree a more extended though a more superficial acquaintance seemed to be required. In fact the matter is so new \& there is so little that can serve as previous experience in the founding and arranging these degrees, that one must leave the whole endeavour to shape itself as the practice \& experience accumulates.

We have had very hot weather but it is \& has been cooler for a fow days- The Thames has very rarely been seen so low in water here, as it is now. In London its bad condition seems to increase; or else my nose accustomed to a better odour here feels it more. The harvest all round us is nearly in ; being very early ; but they tell me the corn is not so heavy as was to be desired. Want of rain has kept it small.

$$
\begin{gathered}
\text { Ever My dear Barlow } \\
\text { Very truly yours } \\
\text { M. Faraday }
\end{gathered}
$$

\section{Dear Mr. Barlow}

My right hand Jane being absent in Scotland I am afraid my husband has promised more for me than I can perform so Mrs. Barlow will kindly take $\mathrm{Mr}$. Faraday's letter as an answer with my best remembrances

$$
\text { Sincerely yours }
$$$$
\text { S. Faraday }
$$

The letter is, first of all, an admirable example of the simplicity and directness of its author's style as a letter writer. It is written from the house on Hampton Court Green which had, only in the previous year, been placed at Faraday's disposal as a summer residence by Her Majesty the Queen - on the Prince Consort's suggestion it is said. The workmen spoken of were engaged that summer on alterations at the Royal Institution, and their strike evidently went on for many weeks, for it was reported in November that the work had been much delayed by it. The Rev. John Barlow, to whom the letter is addressed, and who was abroad on holiday with his wife, was at the time nearing the end of a long period of office as secretary of the Royal Institution. The correspondence which is preserved shows that out of their association in the business of the Institution there had grown up, between the Faradays and the Barlows, a close and affectionate friendship.

John Tyndall, whose lectures and activities in Switzerland are mentioned, had been Faraday's 
junior colleague since his appointment to the professorship of natural philosophy in 1853, and had long since been admitted to the intimate circle of the home at Albemarle Street. That Tyndall's search for rocksalt of optical quality was ultimately successful is evident from the valuable collection of prisms, lenses and rough blocks of the mineral, formerly his property and used in his researches, now in the possession of the Royal Institution. A large block was presented to him by the King of Würtemburg in $\mathbf{1 8 6 7 .}$
The letter contains one of Faraday's not infrequent references to his loss of memory-and a complaint on a different matter, the insanitary condition of the River Thames, a favourite topic, his strictures on which had provoked, a few years earlier, a cartoon in Punch of Prof. Faraday, holding his nose, rebuking Father Thames from the side of a steamboat.

The postscript is in Mrs. Faraday's handwriting, and the reference is to their niece Jane Barnard, who lived with them at the Royal Institution.

T. M.

\section{Obituary}

Prof. H. L. Le Chatelier, For. Mem.R.S.

THE death of Henry Louis Le Chatelier, which occurred at Miribel-les-tichelles on September 17 , removes one of the great pioneers in the physical chemistry of the last quarter of the nineteenth century; he was born in Paris on October 8, 1850. His father, Louis Le Chatelier, who died in 1873, was a man of high technical abilities and scientific talents; in 1842, when France possessed only six hundred kilometres of railroads, he was put in charge of railway development and became largely responsible for the construction of the present French railway network. Louis also played a great part in the perfection of the locomotive, in the improvement of coal mining and utilization, in the manufacture of open hearth steel and of aluminium and in the organization of the Bordeaux pine forests.

The intense application of scientific methods to practical ends which marked the career of the father, gave direction to the life-work of the son. Henry Le Chatelier was essentially a scientific man of great talents and resource but most of his work seemed to aim at some technical application; the tendency of his mind was well shown in a money gift which he made to the Academie des Sciences in 1922 with a condition that the income should be given to "persons possessed of such scientific aptitude and facilities for work as would enable them to carry out essentially scientific work involving precise measurements which would be sooner or later applicable to industry". The same interests were manifested in the frequent occasions on which he exhorted his countrymen to apply scientific methods to the improvement of industrial practice; the work of F. W. Taylor in the United States on scientific management first obtained publicity in France through Le Chatelier's writings.

Le Chatelier was educated at the College Rollin, the Ecole Polytechnique and the Ecole des Mines; he taught at the latter school and at the College de France and in 1907 succeeded Moissan as professor at the Sorbonne. As the fundamental importance of his work became universally recognized, honours came in rapid succession. He was a Grand Officer of the Legion d'Honneur and was elected to the Chemistry Section of the Academie des Sciences in 1907; he became a foreign member of the Royal Society in 1913 and received the Davy Medal in 1916. He was made a foreign member of the Chemical Society in 1908 and an honorary member of the Institute of Metals in 1913; an associate member of the Academie Royale de Belgique in 1913, a foreign member of the Accademia dei Lincei in 1918, and an Ehrenmitglied of the German Chemical Society in 1931. He was a President d'Honneur of the French Chemical Society and probably its senior member, having been elected in 1878 .

Le Chatelier early devoted himself to the study of the thermal changes which accompany cheraical reactions and dissociations, following in this Berthelot and his teacher Sainte-Claire Deville; his work on this subject is monumental and he contributed much to the application of thermodynamics to chemical reactions. His experimental work was characterized by a delicacy previously unknown and was accompanied by mathematical analysis of a searching character ; thus, he was able to predict that calcium carbonate should be appreciably dissociated by water vapour at the ordinary temperature and to show experimentally that the prediction is correct. His great generalization now known as the principle of mobile equilibrium dates from 1884 and states that "toute transformation infiniment petite d'un systeme en equilibre chimique qui est produite par la variation d'un seul des facteurs de l'equilibre s'éffectue dans un sens tel qu'elle tende a produire une variation en sens inverse du facteur considéré". He introduced great improvements in the methods of determining heats of reactions, specific heats of gases at high temperatures, explosion pressures and in the optical measurement of high temperatures. He made the thermoelement an efficient instrument for the determination of high temperatures in face of the criticisms of Regnault, who thought that the use of such an appliance involved sources of error. which could not be eliminated; he was the first to use the platinumplatinum-rhodium thermoelement in thermochemical practice. Le Chatelier established a number of 